\title{
Deriving the effect of wind speed on clean marine aerosol optical properties using the A-Train satellites
}

\author{
V. P. Kiliyanpilakkil and N. Meskhidze \\ Department of Marine, Earth and Atmospheric Sciences, North Carolina State University, Raleigh, NC, USA
}

Received: 27 January 2011 - Published in Atmos. Chem. Phys. Discuss.: 8 February 2011

Revised: 30 October 2011 - Accepted: 3 November 2011 - Published: 16 November 2011

\begin{abstract}
The relationship between "clean marine" aerosol optical properties and ocean surface wind speed is explored using remotely sensed data from the Cloud-Aerosol $\mathrm{Li}$ dar with Orthogonal Polarization (CALIOP) on board the CALIPSO satellite and the Advanced Microwave Scanning Radiometer (AMSR-E) on board the AQUA satellite. Detailed data analyses are carried out over 15 regions selected to be representative of different areas of the global ocean for the time period from June 2006 to April 2011. Based on remotely sensed optical properties the CALIPSO algorithm is capable of discriminating "clean marine" aerosols from other types often present over the ocean (such as urban/industrial pollution, desert dust and biomass burning). The global mean optical depth of "clean marine" aerosol at $532 \mathrm{~nm}\left(\mathrm{AOD}_{532}\right)$ is found to be $0.052 \pm 0.038$ (mean plus or minus standard deviation). The mean layer integrated particulate depolarization ratio of marine aerosols is $0.02 \pm 0.016$. Integrated attenuated backscatter and color ratio of marine aerosols at $532 \mathrm{~nm}$ were found to be $0.003 \pm 0.002 \mathrm{sr}^{-1}$ and $0.530 \pm 0.149$, respectively. A logistic regression between $\mathrm{AOD}_{532}$ and $10-\mathrm{m}$ surface wind speed $\left(U_{10}\right)$ revealed three distinct regimes. For $U_{10} \leq 4 \mathrm{~m} \mathrm{~s}^{-1}$ the mean CALIPSOderived $\mathrm{AOD}_{532}$ is found to be $0.02 \pm 0.003$ with little dependency on the surface wind speed. For $4<U_{10} \leq 12 \mathrm{~m} \mathrm{~s}^{-1}$, representing the dominant fraction of all available data, marine aerosol optical depth is linearly correlated with the surface wind speed values, with a slope of $0.006 \mathrm{~s} \mathrm{~m}^{-1}$. In this intermediate wind speed region, the $\mathrm{AOD}_{532}$ vs. $U_{10}$ regression slope derived here is comparable to previously reported values. At very high wind speed values $\left(U_{10}>18 \mathrm{~m} \mathrm{~s}^{-1}\right)$, the $\mathrm{AOD}_{532}$-wind speed relationship showed a tendency toward leveling off, asymptotically approaching value of 0.15 . The conclusions of this study regarding the aerosol extinc-
\end{abstract}

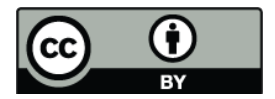

Correspondence to: N. Meskhidze (nmeskhidze@ncsu.edu) tion vs. wind speed relationship may have been influenced by the constant lidar ratio used for CALIPSO-derived $\mathrm{AOD}_{532}$. Nevertheless, active satellite sensor used in this study that allows separation of maritime wind induced component of AOD from the total AOD over the ocean could lead to improvements in optical properties of sea spray aerosols and their production mechanisms.

\section{Introduction}

Marine aerosols play significant role in global energy budget; they influence the planetary radiation balance directly by scattering and absorbing sunlight and indirectly by modifying cloud microphysical properties (Clarke and Kapustin, 2003; Murphy et al., 1998; Pierce and Adams, 2006). As cloud properties are most sensitive to the addition of particles when the background concentration is low (Platnick and Twomey, 1994), marine aerosols are very important for understanding the cloud-mediated effects of aerosols on climate (Andreae, 2007). Because the anthropogenic contribution to climate forcing represents the difference between the total forcing and that from natural aerosols, the accurate information about the background levels of aerosols or the "aerosols before pollution" is necessary for correct assessment of the role of anthropogenic aerosols in climate change (Penner et al., 1994; Andreae, 2007).

Marine aerosols have different natural sources that can be broadly classified as primary, i.e. derived from the mechanical process of bubble bursting, and secondary, derived through ocean emission of precursor biogenic volatile organic compounds (Blanchard and Woodcock, 1957 and references therein; O'Dowd and de Leeuw, 2007). Although sea salt particles, frequently associated with clean marine aerosol, are often a major component of aerosol mass over the remote oceanic regions (Prospero, 2002; Lewis and Schwartz, 2004), it was shown that sulfates from the

Published by Copernicus Publications on behalf of the European Geosciences Union. 
oxidation of biogenic dimethylsulfide (DMS) and ocean produced organics could also contribute considerably to total aerosol budget (Shaw, 1983; Charlson et al., 1987; O'Dowd et al., 2004; Meskhidze and Nenes, 2006; de Leeuw et al., 2011).

The dependency of marine aerosol optical properties on sea surface wind speed and sea state has been examined by numerous investigators. Based on the measurements from Minicoy Island in the Arabian Sea, Moorthy and Satheesh (2000) derived an exponential relationship between aerosol optical depth (AOD) and surface wind speed. Smirnov et al. (2003a) studied the effects of surface wind speed on aerosol optical properties using ground based AErosol RObotic NETwork (AERONET) (Holben et al., 1998) located on Midway Island in the Pacific Ocean. Shinozuka et al. (2004) explored sea-salt contribution to AOD over the tropical Pacific Ocean and the Southern Ocean. Huang et al. (2010) derived relationship between AOD from Advanced Along-Track Scanning Radiometer (AATSR) onboard European Space Agency's Envisat and $10 \mathrm{~m}$ wind speed from the European Centre for MediumRange Weather Forecasts (ECMWF). Glantz et al. (2009) reported a power-law fit between Sea-viewing Wide Field-ofview Sensor (SeaWiFS) retrieved AOD and ECMWF wind speed over the Northern Pacific ocean. Based on the measurements of aerosol properties at the Mace Head atmospheric research station under moderately windy conditions, Mulcahy et al. (2008) established a power-law relationship between marine AOD and surface wind speed. Using a systematic comparison between multiple satellite-retrieved surface wind speed values, MODIS-derived AOD, and aerosol fine mode fraction, Lehahn et al. (2010) managed to isolate the marine component of AOD over the ocean and quantify its dependence on surface wind speed. Table 1 summarizes available regression statistics of AOD versus wind speed.

Although the effect of wind speed on marine aerosol optical properties was thoroughly studied over the last several decades, comprehensive quantification of marine aerosols using remotely-sensed and ground-based measurement data suffered from a number of difficulties. The sensors were not able to make explicit distinction of "clean marine" aerosols from ones influenced by the terrestrial sources (i.e. mineral dust, biomass burning, anthropogenic pollution). Passive instruments used in earlier studies of marine aerosol optical properties also could not give vertical distribution of aerosols over the ocean nor could retrieve aerosols over the regions without sunlight (e.g. at night and north/south of the Arctic and the Antarctic Circles, respectively), above continuous cloud cover, or beneath thin cirrus (Winker and Pelon, 2003). In this study, we expand upon previous satellite remote sensing analyses by employing a novel approach that allows an explicit distinction of "clean marine" aerosols properties from those of other aerosol subtypes through the use of the Cloud-Aerosol Lidar and Infrared Pathfinder Satellite Observation (CALIPSO) satellite. Due to its unique capabili-
Table 1. Regression statistics of aerosol optical depth versus wind speed.

\begin{tabular}{lll}
\hline Regression relation & $r^{2}$ & Reference \\
\hline $\mathrm{AOD}_{532}=\frac{0.15}{1+6.7 \cdot \mathrm{e}^{-0.17 \cdot U_{10}}}$ & $0.97^{\mathrm{a}}$ & Current work \\
$\mathrm{AOD}_{500, \mathrm{SM}}=0.0068 \cdot U_{10}+0.056$ & $0.25^{\mathrm{b}}$ & \\
$\mathrm{AOD}_{500, \mathrm{SH}}=4.9 \cdot 10^{-5} \cdot U_{10}^{3}-3.7 \cdot 10^{-5} \cdot U_{10}^{2}+0.017$ & $\mathrm{NA}^{\mathrm{c}}$ & Shinozuka et al. (2004) \\
$\mathrm{AOD}_{550, \mathrm{~cm}}=0.009 \cdot\left(U_{10}-4\right)+0.03$ & 0.50 & Lehahn et al. (2010) \\
$\mathrm{AOD}_{550, \mathrm{~m}}=0.013 \cdot\left(U_{10}-4\right)+0.08$ & 0.45 & Lehahn et al. (2010) \\
$\mathrm{AOD}_{555, \mathrm{GL}}=0.00016 \cdot U_{10}^{2.3}+0.036$ & 0.98 & Glantz et al. (2009) \\
$\mathrm{AOD}_{500, \mathrm{ML}}=0.00055 \cdot U^{2.195}+0.06$ & 0.97 & Mulcahy et al. (2008) \\
$\mathrm{AOD}_{550, \mathrm{H}}=0.004 \cdot U_{10}+0.085$ & 0.95 & Huang et al. (2010) \\
\hline
\end{tabular}

a Correlation between logistic regression line and wind speed bin-averaged AOD values.

${ }^{\mathrm{b}}$ Correlation between logistic regression line and all 539, 549 collocated instantaneous AOD and $U_{10}$ values.

${ }^{\mathrm{c}}$ NA stands for not available.

ties, such as accurate determination of the vertical location of aerosols and the ability to retrieve aerosol properties during the night as well as the day, CALIPSO can give new insight into the marine aerosol wind speed relationship.

\section{Data analysis and methods}

The wind speed dependence of marine aerosol optical depth is estimated using nearly five years (June 2006 to April 2011) of remotely sensed AOD data from the Cloud-Aerosol Lidar with Orthogonal Polarization (CALIOP) onboard the CALIPSO satellite and the surface wind speed data from the Advanced Microwave Scanning Radiometer for EOS (AMSR-E) onboard the AQUA satellite. Two different types of data analysis were carried out. In the general analysis, the physical and optical properties of the CALIOP marine aerosol layers were calculated over the entire global ocean, while in the detailed analysis, the datasets selected over numerous oceanic regions were compared to derive the relationship between marine aerosol optical depth and surface wind speed.

\subsection{Remotely sensed data/instruments}

CALIPSO provides aerosol and cloud optical properties using a two wavelength $(532 \mathrm{~nm}$ and $1064 \mathrm{~nm})$ polarization sensitive lidar, CALIOP, an Imaging Infrared Radiometer (IIR), and a Wide Field Camera (WFC) (Winker et al., 2009; Hunt et al., 2009). The CALIPSO retrieval algorithm considers scattering properties from particles and molecules, where molecular scattering properties are determined from the Global Modeling and Assimilation Office (GMAO) meteorological data (Vaughan et al., 2004, 2009; Young and Vaughan, 2009; Omar et al., 2009; Liu et al., 2009). In this study we use Level 2, version 3.01 "clean marine" aerosol layer properties from CALIPSO derived at $5 \mathrm{~km}$ horizontal 
resolution. The CALIPSO marine aerosol layer products were spatially and temporally collocated with Level 3, version 5 gridded AMSR-E-derived daily surface wind speed at $0.25^{\circ} \times 0.25^{\circ}$. As both sensors are located on satellites that are part of the A-Train constellation (CALIOP on the CALIPSO and AMSR-E on the Aqua) (Hu et al., 2008; Kittaka et al., 2011; L'Ecuyer and Jiang, 2010), virtually the same scene is viewed by the sensors as CALIPSO flies about $75 \mathrm{~s}$ behind the Aqua satellite. Both CALIPSO lidar and AMSR-E are capable of collecting day and night observations (Hu et al., 2008). In this study AMSR-E wind speed and CALIPSO layer optical properties from ascending (equatorial crossing time at 13:30 local time) and descending (equatorial crossing time at 01:30 local time) passes were used.

The CALIPSO algorithm is distinctive from other satellite algorithms in its capability to discriminate marine aerosols from other subtypes (such as clean continental, desert dust, polluted continental, polluted dust, and smoke) (Omar et al., 2009). The aerosol optical depth as well as extinction and backscatter profile retrievals require particulate extinction to backscatter ratio also known as lidar ratio $\left(S_{\mathrm{a}}\right)$. The $S_{\mathrm{a}}$ is an intensive aerosol property, i.e. a property that does not depend on a number density of the aerosol but rather on such physical and chemical properties as size distribution, shape and composition. The type and subtype information of the layer is used to estimate initial $S_{\mathrm{a}}$, whereas a final $S_{\mathrm{a}}$ is derived by applying transmittance correction to the extinction processing (Omar et al., 2004, 2009; Young and Vaughan, 2009). Only the high confidence retrievals (aerosol layers with the same initial $S_{\mathrm{a}}$ and final $S_{\mathrm{a}}$ ) are used in the current analysis (Kittaka et al., 2011). Level 2 version 3.01 CALIPSO aerosol subtypes are defined with 532-nm and $1064 \mathrm{~nm}$ lidar ratios (mean plus or minus standard deviation) as clean continental $(35 \pm 16 \mathrm{sr}$ and $30 \pm 17 \mathrm{sr})$, clean marine ( $20 \pm 6 \mathrm{sr}$ and $45 \pm 23 \mathrm{sr})$, desert dust $(40 \pm 20 \mathrm{sr}$ and $55 \pm 17 \mathrm{sr})$, polluted continental $(70 \pm 25 \mathrm{sr}$ and $30 \pm 14 \mathrm{sr})$, polluted dust ( $55 \pm 22 \mathrm{sr}$ and $48 \pm 24 \mathrm{sr}$ ), and biomass burning (70 $\pm 28 \mathrm{sr}$ and $40 \pm 24 \mathrm{sr}$ ) (Cattrall et al., 2005; Omar et al., 2005, 2009; Mielonen et al., 2009). In Level 2 aerosol layer products, CALIPSO provides vertically resolved aerosol properties for up to 8 aerosol layers in a column and each layer is further classified into one of six aerosol subtypes. For most of the aerosol types used in CALIPSO retrieval algorithm, the size distributions and complex refractive indices are based on AERONET-derived model parameters. However, clean marine aerosol properties used in the CALIPSO aerosol-type identification algorithm are not derived from AERONET, as the marine aerosol cluster is comprised of a small number of records $(<4 \%$ of the total) (Omar et al., 2005, 2009). In addition, most AERONET oceanic sites are actually land based and therefore may not be free from terrestrial and anthropogenic influences (Omar et al., 2009). Therefore, the $S_{\text {a }}$ value for CALIPSO clean marine aerosol was derived using Mie theory with the sea spray aerosol size distribution measured during the Shore- line Environmental Aerosol Study (SEAS) experiment (Masonis et al., 2003; Omar et al., 2004, 2009). It should be noted, however, that measurements and model calculations often report a wide range $\left(20 \leq S_{\mathrm{a}} \leq 90\right.$ at $\left.532 \mathrm{~nm}\right)$ in $S_{\mathrm{a}}$ values for clean marine aerosol, with different magnitudes for sub-micron (with equilibrium radius at relative humidity of $\left.80 \%, r_{80}<1 \mu \mathrm{m}\right)$ and super-micron $\left(r_{80}>1 \mu \mathrm{m}\right)$ sized aerosols (Welton et al., 2002; Masonis et al., 2003; Cattrall et al., 2005). The bias and variance in the assumed value of $S_{\mathrm{a}}$ creates errors in both backscatter and extinction profiles and can strongly influence AOD retrievals. Section 4 gives a brief summary of some of the caveats and uncertainties in CALIPSO sea spray AOD calculations related to the uncertainty in $S_{\mathrm{a}}$ value of clean marine aerosol.

The CALIOP separates clouds and aerosols and provides the cloud-aerosol discrimination (CAD) score for each layer (Liu et al., 2004, 2005, 2009; Vaughan et al., 2005). The standard CAD scores in the CALIPSO layer products range from -100 to 0 for aerosols and from 0 to +100 for clouds. Larger absolute value of CAD indicates higher confidence in the aerosol-cloud feature classification. The CALIPSO aerosol optical depths are provided at wavelengths $532 \mathrm{~nm}$ and $1064 \mathrm{~nm}$. To extract marine aerosol types and the corresponding aerosol optical thicknesses, we have used CAD score of -70 to -100 which gives high confidence cloud cleared optical thickness layer data (Kittaka et al., 2011; Liu et al., 2009; Omar et al., 2009). To reduce uncertainties and increase quality assessment and reliability of layer optical depth, only aerosol layers corresponding to values from 0 to $0.01 \mathrm{sr}^{-1}$ of integrated attenuated backscatter at $532 \mathrm{~nm}$, values from 0 to 0.1 of estimated uncertainty of layer optical depth at $532 \mathrm{~nm}$, and values from 0 to 2.0 of integrated attenuated total color ratio are used in the current analysis. The information provided by the layer integrated particulate depolarization ratio, extinction quality control values, and opacity flag of the layers are also used to retrieve high confidence aerosol layers (Kittaka et al., 2011; Liu et al., 2005; http://eosweb.larc.nasa.gov/PRODOCS/calipso/ Quality_Summaries/CALIOP_L2LayerProducts_3.01.html, last access: September 2011).

As part of NASA's Aqua satellite's global hydrology mission, over the oceans AMSR-E derives wind speed, sea surface temperature (SST), atmospheric water vapor, cloud water, and rain rate (Wentz and Meissner, 2000, 2007; Wentz et al., 2003). Passive microwave frequencies used by AMSRE sensor allow it to "see" through clouds, thus providing continuous global surface wind observations (Wentz et al., 2003). The value of AMSR-E-derived $10 \mathrm{~m}$ daily surface wind speed $\left(U_{10}\right)$ over the sea surface is determined by the surface roughness (caused by the wind stress) and is processed based on National Centers for Environmental Prediction (NCEP) reanalysis wind direction. Missing data can be caused by regions of sun glint, near sea ice, and proximity to land $(\sim 50 \mathrm{~km})$ (Wentz and Meissner, 2007). Under typical ocean conditions AMSR-E retrieved wind speed data 
compares well to surface buoy observations with the negligible bias and root mean square (rms) difference $<1 \mathrm{~m} \mathrm{~s}^{-1}$ (Wentz and Meissner, 2000; Mears et al., 2001; Bourassa et al., 2009). However, the AMSR-E data validation at high wind speeds (winds greater than $20 \mathrm{~m} \mathrm{~s}^{-1}$ ) is limited due to the scarcity of such events that are often located in data-poor remote regions and the questionable measurements of buoys or ships in rough oceans due to wave sheltering (Bourassa et al., 2009).

\subsection{Data selection and analysis}

The regression statistics for the dependency of marine aerosol optical properties on $U_{10}$ were calculated for the selected 15 regions of interest covering all the major parts of the global oceans (see Fig. 1a and Table S1 in Supplement). Although CALIPSO can distinguish different aerosol species, to minimize the contribution from terrestrial sources the regions were selected to be far from the known transport pathways of anthropogenic pollutants and mineral dust. The midpoint of each $5 \mathrm{~km}$ high confidence single-layer clean marine aerosol data were spatially and temporally collocated with the gridded $\left(0.25^{\circ} \times 0.25^{\circ}\right)$ AMSR-E-derived $U_{10}$. Previous studies have shown that due to the downward propagations of bias errors into detected layers, the incorrect choice of $S_{\mathrm{a}}$ for the upper aerosol layers may cause errors in transmission corrections, causing large uncertainties for multi-layer aerosol retrievals (Winker et al., 2009; Weitkamp, 2005; Young and Vaughan, 2009). Data analyses carried out in this study revealed (see below) that the vast majority of marine aerosol layer tops were placed within $2 \mathrm{~km}$ of the mean sea level. Therefore, to reduce the erroneous classification of elevated aerosol layers over the ocean (Omar et al., 2009) only single-layer AODs below $2 \mathrm{~km}$ height above sea level were used for the analysis. Collocated aerosol measurements for the selected regions were merged together and the resultant dataset was sorted into bins based on the wind speed. The bins were spaced in $1 \mathrm{~m} \mathrm{~s}^{-1}$ increments between $0<U_{10} \leq 29 \mathrm{~m} \mathrm{~s}^{-1}$.

\section{Results and discussion}

\subsection{Physical and optical properties of the CALIOP marine aerosol layers}

The available CALIPSO data products can be analyzed in terms of aerosol extensive and intensive properties. Extensive parameters depend directly on particulate amount within the scattering volume, while intensive properties are independent of aerosol loading and depend only on optical properties as determined by aerosol composition, size and shape (Vaughan et al., 2004; Rogers et al., 2009). Figure 1 shows global seasonal maps of CALIPSO-derived marine aerosol extensive property - optical depth. This figure reveals the large spatial and temporal variations in marine
$\mathrm{AOD}$ at $532 \mathrm{~nm}\left(\mathrm{AOD}_{532}\right)$. Inspection of Fig. 1 shows that the largest values of $\mathrm{AOD}_{532}$ occur over the regions with elevated surface wind speed (i.e. northern and southern oceans), with the highest values found over the Southern Hemisphere mid-latitude oceans during austral winter (JJA) season. Regions of moderate winds typically have relatively low values of AODs. The exceptions are the regions downwind from dust and/or pollution sources such as mid-latitude North Atlantic Ocean and the Bay of Bengal (BoB), suggesting that some dust/pollution aerosols might have been misclassified as sea salt (see Fig. 1). Figure 1c shows sporadic retrievals of aerosols over BoB during the summer season, most likely due to thick, extensive cloud cover associated with the intense summertime monsoon season. The calculated AOD $_{532}$ is consistent with the baseline aerosol over the Pacific $\left(\mathrm{AOD}_{500}=0.052\right)$ and Atlantic $\left(\mathrm{AOD}_{500}=0.071\right)$ Oceans, reported by Kaufman et al. (2001). Calculated global mean $\mathrm{AOD}_{532}$ is also in a good agreement with $\mathrm{AOD}_{500}=0.06$, the most frequently occurring value of aerosol optical depth over the Central Pacific Ocean (Smirnov et al., 2003a, b) and within the range $0.02<\mathrm{AOD}_{550}<0.067$ of sixteen global models participated in the Aerosol Comparisons between Observations and Models (AeroCom) Experiment-A (Rind et al., 2009). The frequency distribution of CALIPSO lidar marine aerosol layer $\mathrm{AOD}_{532}$ for 15 selected regions over the time period of June 2006 to April 2011 is shown in Fig. 2. It was found that approximately $99.5 \%$ of clean marine aerosol layers had $\mathrm{AOD}_{532}<0.2$, with $\mathrm{AOD}_{532}=0.03$ being the most frequently occurring value.

The vertical distribution of marine aerosols for variable wind conditions and seasons was obtained by detailed inspection of the frequency of occurrences of marine aerosols with different layer base and layer top altitudes. Figure 3 shows that optically active marine aerosols are generally confined within $2 \mathrm{~km}$ above mean sea level with little transport to higher altitudes in the troposphere. For the entire study period, virtually all CALIPSO-retrieved marine aerosol layer bases were below $0.5 \mathrm{~km}$ and $96 \%$ of aerosol layer tops were below $2 \mathrm{~km}$ above sea level (Fig. 3), suggesting that the $2 \mathrm{~km}$ layer threshold selected in this study captures the majority of optically active marine aerosols. This result is in a good agreement with ambient measurements (e.g. Maring et al. (2003) found no evidence of sea-salt aerosols above the marine boundary layer, MBL), model results (e.g. Grini et al. (2002) found no significant amount of sea salt mass above $750 \mathrm{hPa}$ ), and remote sensing (e.g. Kaufman et al. (2005), based on correlation between the wind speed and the AOD, suggested that sea salt aerosols should reside largely in the lowest $500 \mathrm{~m}$ of the atmosphere). Although marine aerosols layer base altitudes do not reveal any considerable variation, Fig. 3 shows dependence of aerosol layer top altitude on seasonality and surface wind speed. According to this figure, $\sim 1 \mathrm{~km}$ height is the most commonly occurring value of the aerosol layer top altitude for the entire study period. Figure $3 \mathrm{a}$ shows that over the Northern Hemisphere $(\mathrm{NH})$ 

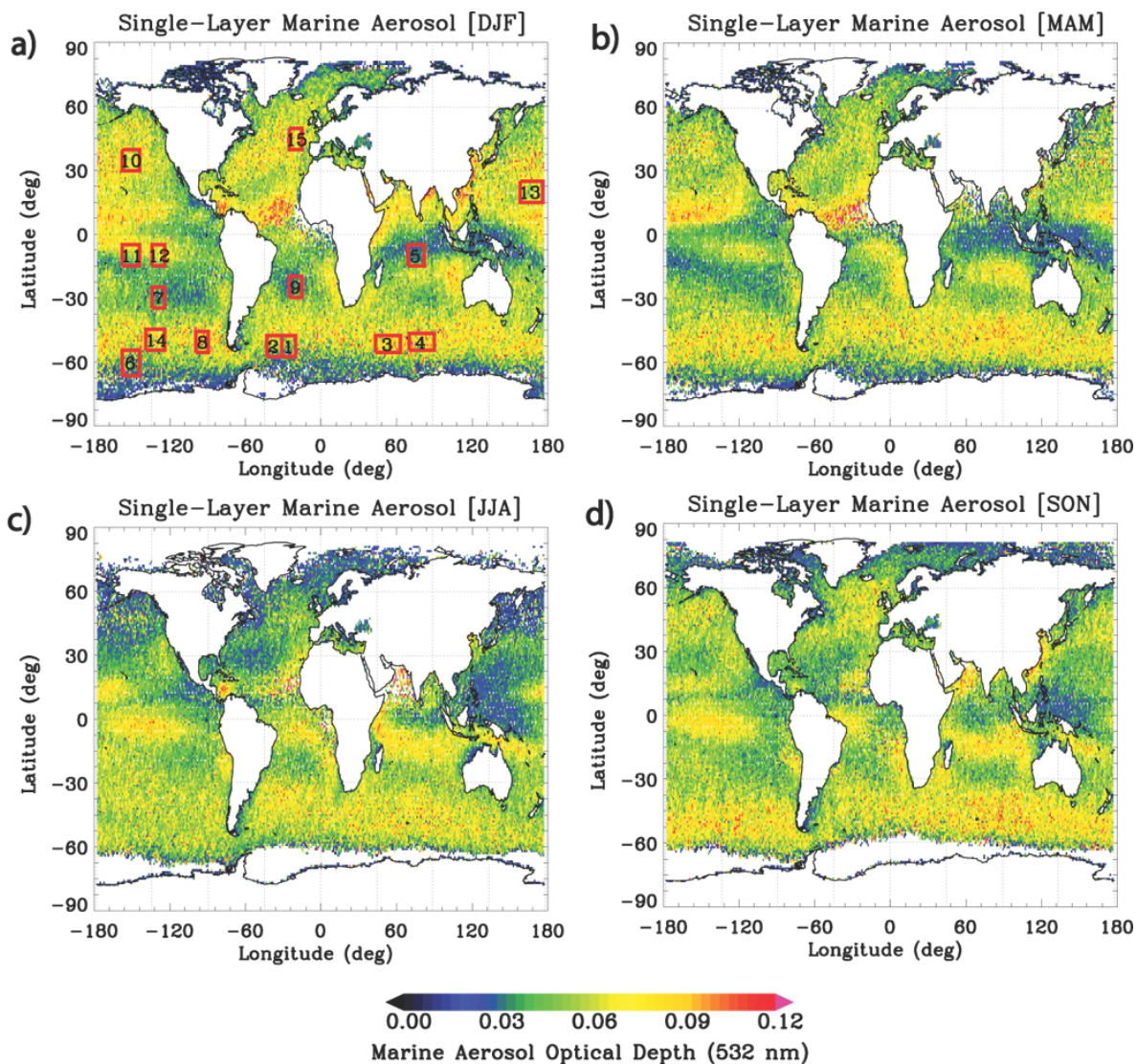

Fig. 1. Global distribution of $1^{\circ} \times 1^{\circ}$ degree averaged CALIPSO level 2 version 3.01 mean AOD 532 for "clean marine" single-layer aerosols. Layer optical depths are averaged for boreal winter (DJF), spring (MAM), summer (JJA), and fall (SON) from June 2006 to April 2011 . Areas surrounded by solid red line in Fig. 1a illustrate the regions selected for the detailed analysis. Latitudes and longitudes of the selected 15 regions are summarized in Table $\mathrm{S} 1$ in Supplement.

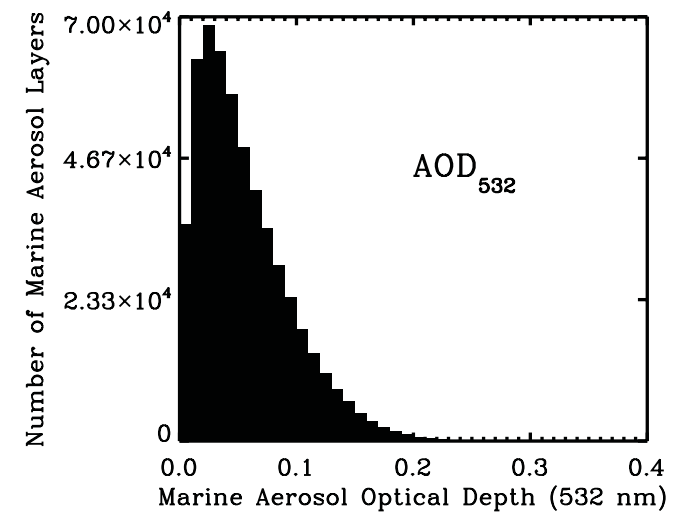

Fig. 2. The CALIPSO lidar marine $\mathrm{AOD}_{532}$ histogram for 15 selected regions over the time period of June 2006 to April 2011.

mid-latitude waters $\left(30^{\circ} \mathrm{N}\right.$ to $\left.60^{\circ} \mathrm{N}\right)$ the seasonal distribution of layer top altitude is positively skewed in winter (DJF) and negatively skewed during the summer (JJA) months. The vertical turbulent transport of sea salt particles and associ- ated changes in aerosol layer heights over the selected $\mathrm{NH}$ mid-latitude regions are likely to be influenced by multiple different parameters including turbulence and convection in MBL, dry and wet removal processes, and location of subtropical highs often leading to strong summertime subsiding motion. Figure $3 \mathrm{~b}$ suggests that there is a positive relationship between surface wind speed and the optically active aerosol layer height. For the surface wind speed values less than $4 \mathrm{~m} \mathrm{~s}^{-1}$ the vast majority of aerosol layer tops are placed below $1.5 \mathrm{~km}$, while for $4<U_{10} \leq 12 \mathrm{~m} \mathrm{~s}^{-1}$ considerable fraction of aerosol later tops occur at close to $2 \mathrm{~km}$ height. For the surface wind speed in excess of $12 \mathrm{~m} \mathrm{~s}^{-1}$, number of occurrences is positively skewed with the frequency of layer top altitudes at $1.8 \mathrm{~km}$ comparable to that at $1 \mathrm{~km}$. Over the Southern Hemisphere (SH) mid-latitude waters $\left(30^{\circ} \mathrm{S}\right.$ to $\left.60^{\circ} \mathrm{S}\right) \mathrm{Fig}$. $3 \mathrm{c}$ shows that layer top altitude is positively skewed during the winter (JJA) and negatively skewed during the summer (DJF) months. Comparison of Fig. $3 \mathrm{~b}$ and $\mathrm{d}$ shows that despite higher wind speed values in the $\mathrm{SH}$, sea salt particles in the $\mathrm{NH}$ are more frequently lifted at higher altitudes compared to the SH. The observed 

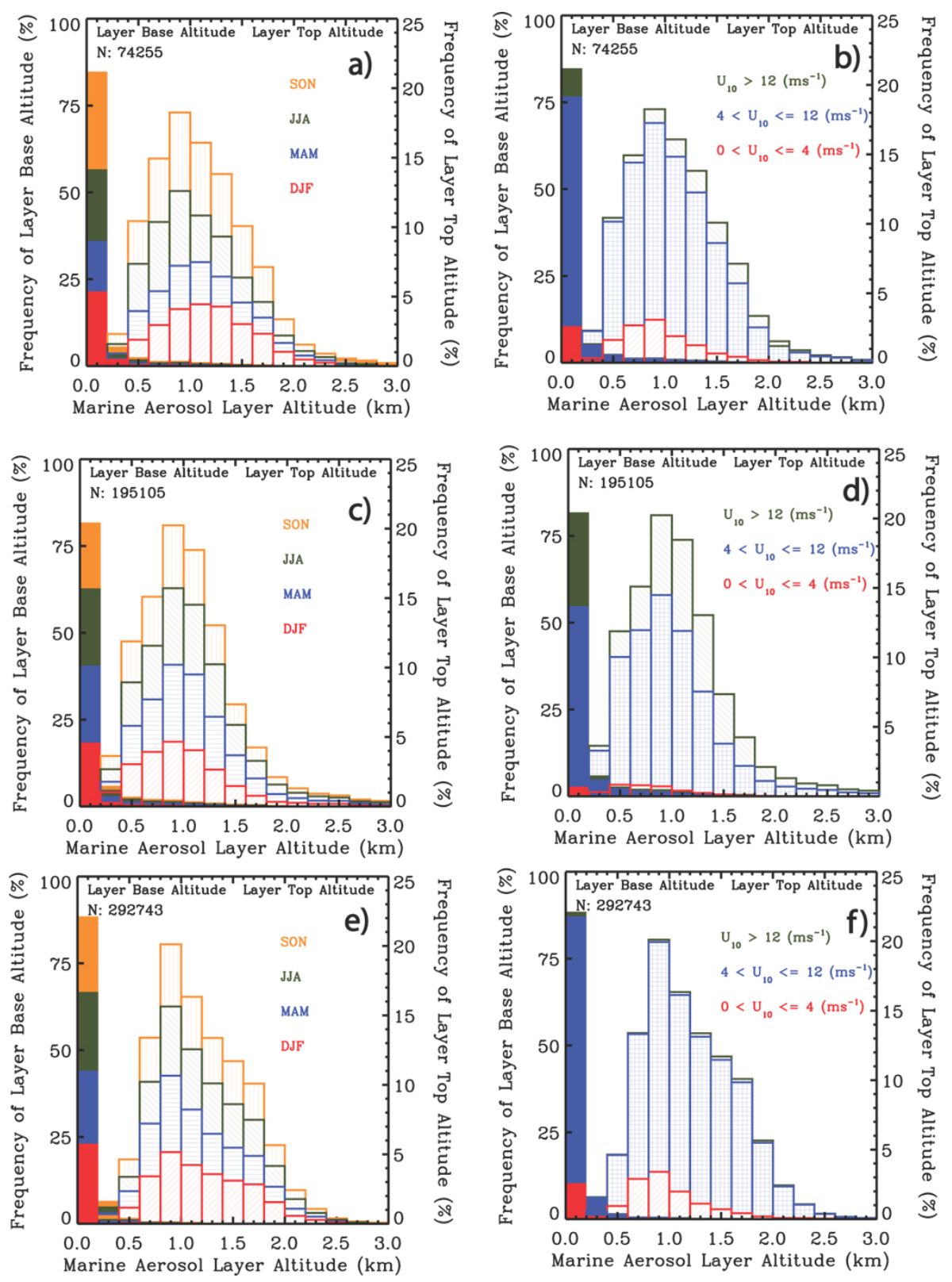

Fig. 3. The CALIPSO lidar frequency histogram of marine $\mathrm{AOD}_{532}$ aerosol layer base height (solid filled histograms), and aerosol layer top height (line filled histograms) as a function of the season (left) and wind speed (right) for the 15 selected regions over the time period of June 2006 to April 2011. The top panel (a, b) shows aerosol layers for regions $30^{\circ} \mathrm{N}$ to $90^{\circ} \mathrm{N}$ (regions 10 and 15 on Fig. 1) the middle panel (c, d) for regions $35^{\circ} \mathrm{S}$ to $90^{\circ} \mathrm{S}$ (regions $1,2,3,4,6,8$, and 14 on Fig. 1) and the lower panel (e, f) $30^{\circ} \mathrm{N}$ to $35^{\circ} \mathrm{S}$ (regions $5,7,9,11,12$, and 13 on Fig. 1). Different color bars represent frequency of occurrences for different data groups.

difference may be associated with SST-related modification of marine atmospheric boundary layer stability and vertical turbulent transport (O'Neill et al., 2003). When considered on the basin scale (larger than about $1000 \mathrm{~km}$ ), very cold waters of the Southern Ocean may have a dominant effect on in capping of the marine boundary layer and causing reduction in the vertical momentum mixing (Xie, 2004). Although, based on the CALIPSO data analysis alone the reason for such a discrepancy between the northern and the Southern
Hemispheres cannot be fully ascertained. Figure $3 e$, f show that in tropical waters $\left(30^{\circ} \mathrm{S}\right.$ to $\left.30^{\circ} \mathrm{N}\right)$ there is no defined seasonality and the frequency of the layer top altitudes are consistently higher compared to $\mathrm{NH}$ and $\mathrm{SH}$ mid-latitude waters. Given relatively low wind speed in this region (Fig. $3 \mathrm{f}$ shows that there are very few cases with $U_{10}>12 \mathrm{~m} \mathrm{~s}^{-1}$ ) such elevated layer tops are likely to be associated with the deep atmospheric convection over tropical oceans. 
Intensive scattering properties of aerosols, such as color ratio (the ratio of aerosol backscatter at the two wavelengths) and aerosol depolarization ratio are also examined to gain some more insight into marine aerosol optical properties. Particle sizes for most marine aerosols exhibit a spectrally dependent scattering efficiency. Due to diffraction of light, large particles are expected show more forward scattering (extinction) (Weitkamp, 2005; Hu et al., 2007). Figure 4a shows that for the majority of layer-integrated aerosols examined over the selected fifteen regions, $\beta_{532}$ is greater than $\beta_{1064}$, indicating that the optically important particles are dominated by super-micron sized particles. The larger values of $\beta_{532}$ compared to $\beta_{1064}$ (smaller backscatter at $1064 \mathrm{~nm}$ than that at 532) resulting in values of layerintegrated attenuated total color ratio $\left(\chi=\beta_{1064} / \beta_{532}\right)$ from $\sim 0.4$ to 0.7 (Fig. 4 b), consistent with the expected values for the marine aerosols (Vaughan et al., 2004; Liu et al., 2005). The integrated attenuated backscatter of single-layer marine aerosols averaged over the entire study period over the selected 15 regions were found to be $\beta_{532}=0.003 \pm 0.002 \mathrm{sr}^{-1}$ and $\beta_{1064}=0.002 \pm 0.001 \mathrm{sr}^{-1}$, yielding $\chi=0.530 \pm 0.149$.

Another intensive property of aerosols, depolarization ratio (or particle non-sphericity) can provide an indication of aerosol shape. Deliquesced sea salt particles are expected to exhibit low depolarization (when neglecting multiple scattering), whereas irregularly shaped particles (e.g. dust) could significantly depolarize the backscattered signal (Liu et al., 2005; Gobbi et al., 2000; Murayama et al., 2001). The layer-integrated particulate depolarization ratio, $\delta_{p}$, calculated as ratio of the layer integrated perpendicular and parallel polarization components of particulate backscatter coefficient $\left(\delta_{p}=\frac{\beta_{\perp, p}}{\beta_{\|, p}}\right)$, is directly related to the hydration state of sea spray aerosol. Figure $4 \mathrm{c}$ shows that the majority of marine aerosols had layer-integrated particulate depolarization ratios at $532 \mathrm{~nm}$ from 0.005 to 0.05 , consistent with linear depolarization ratios reported for sea salt crystals $(0.08 \pm 0.01)$ and deliquesced droplets $(0.01 \pm 0.001)$ (Sakai et al., 2010). The mean layer-integrated particulate depolarization ratio of single-layer marine aerosols obtained in this study $\delta_{p}=0.02 \pm 0.016$, suggesting that most of the optically important sea spray aerosols in the marine boundary layer are likely to be deliquesced and exhibit optical properties of droplets. Overall, detailed analyses of clean marine aerosol intensive scattering properties suggest that large majority of optically important particles in the selected fifteen regions had physical and optical properties characteristic of sea salt. In the next chapter CALIPSO retrievals will be used to derive relationship between surface wind speed and marine aerosol optical depth. Some potential differences between CALIPSO-retrieved "clean marine" aerosols and natural marine aerosols will also be addressed in Sect. 4 .
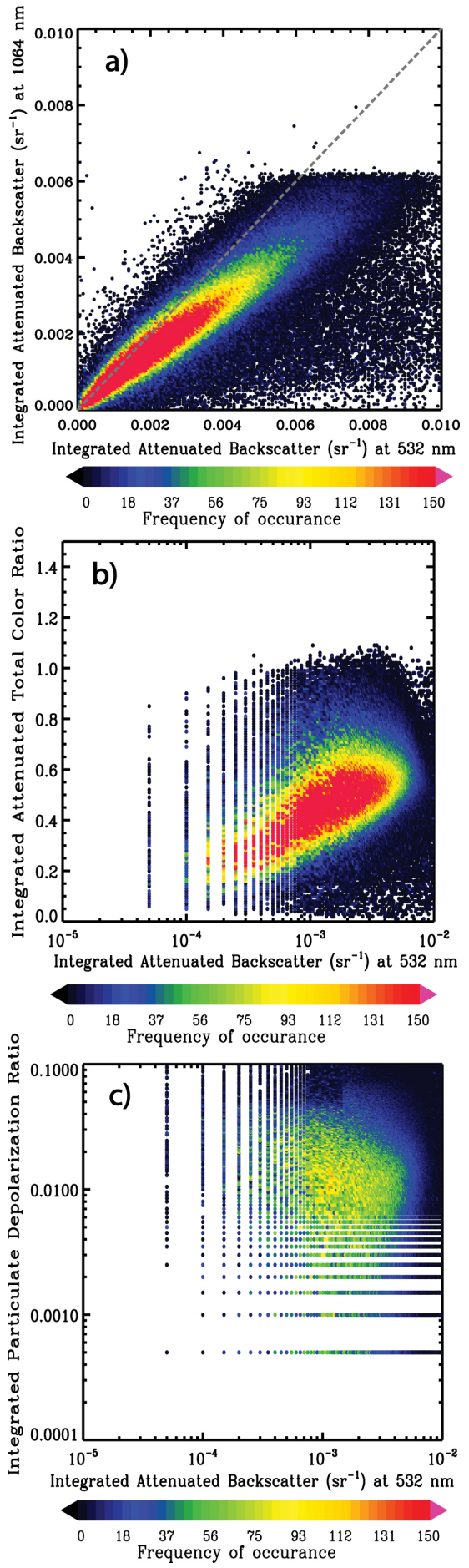

Fig. 4. The CALIPSO lidar relationships for (a) $\beta_{1064}-\beta_{532}$ (b) $\chi-$ $\beta_{532}$ and (c) $\delta_{p}-\beta_{532}$ for 15 selected regions over the time period of June 2006 to April 2011. The color of each pixel represents the frequency of occurrence and the dashed line on Fig. 4a indicates 1:1 ratio. 


\subsection{Regression statistics for $\mathrm{AOD}_{\mathbf{5 3 2}}$-wind speed relationships}

The relationship between collocated CALIPSO-AOD 532 and AMSR-E wind speed at selected marine regions is shown on Fig. 5. According to Fig. 5 the majority of all the $\mathrm{AOD}_{532}$ retrievals $(84.8 \%$ of all available data) fall between $2 \mathrm{~m} \mathrm{~s}^{-1}<U_{10} \leq 12 \mathrm{~m} \mathrm{~s}^{-1}$ wind speed values. Our calculations indicate that the remaining number of retrievals fall between $12<U_{10} \leq 24 \mathrm{~ms}^{-1}$ wind speed values $(13.7 \%$ of retrievals or 73944 instances) and $U_{10} \leq 2 \mathrm{~m} \mathrm{~s}^{-1}$ (1.5\% of retrievals or 8208 instances). Although very few data points are available for the wind speeds above $24 \mathrm{~m} \mathrm{~s}^{-1}(0.02 \%$ of retrievals or 95 instances) these data point were also included in the current study for the completeness. Removal of these points also does not change the conclusions drawn from the data analysis. Using the MATLAB curve fitting tool we have developed a logistic function for the CALIPSO-derived AOD532 and AMSR-E wind speed relationship. The results of our analysis show that the logistic regression $\mathrm{AOD}_{532}=\frac{0.15}{1+6.7 \cdot \mathrm{e}^{-0.17 \cdot U_{10}}}$ provides the best fit for marine aerosol optical depth and 10-m surface wind speed relationship. High correlation $\left(r^{2}=0.97\right)$ between logistic regression line and wind speed bin-averaged AOD values suggests that proposed regression equation gives robust measure for global, spatiotemporally averaged sea salt AOD as a function of surface wind speed. However, when all (over half a million) collocated data points of AOD and wind speed are considered, the correlation reduces considerably $\left(r^{2}=0.25\right)$ highlighting the importance of the wind speed history for the generation of sea salt aerosol prior to retrieval (e.g. Smirnov et al., 2003a; Mulcahy et al., 2008). We prefer logistic regression over linear, exponential or power-law relationships because logistic regression better captures three distinct regions in AOD versus $U_{10}$ relationship shown on Fig. 5. For the $U_{10} \leq 4 \mathrm{~m} \mathrm{~s}^{-1}$ marine aerosol optical depth is only weakly related to wind speed. For the intermediate wind speed values $4<U_{10} \leq 12 \mathrm{~m} \mathrm{~s}^{-1}$, AOD 532 increases qasi-linearly with the increase in surface wind. Finally, for higher wind speed values $\left(U_{10}>18 \mathrm{~m} \mathrm{~s}^{-1}\right)$ the aerosol effects on optical turbidity of air appear to level off.

The regional differences in $\mathrm{AOD}_{532}$ dependence on surface wind speed are examined in Fig. S1 in Supplement. This figure shows that compared to the mean logistic regression for marine aerosol optical depth and 10-meter surface wind speed, mid- and high-latitudes (low SST) show somewhat lower, while tropics (high SST) show higher $\mathrm{AOD}_{532}$ values. Similar dependence of sea salt AOD on wind speed was noticed by Jaeglé et al. (2011). It was suggested that temperature, through its effect on kinematic viscosity of water, can influence the terminal velocity of rising air bubbles as well as the wave breaking and a lifetime of individual whitecaps (Jaeglé et al., 2011). Laboratory experiments also revealed considerable increase in production of sea salt (with diameter $>0.35 \mu \mathrm{m}$ ) with increasing water temperatures from $5^{\circ} \mathrm{C}$

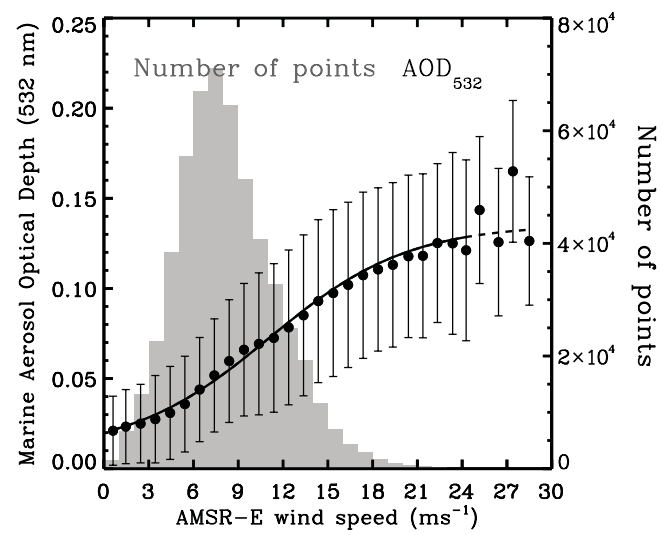

Fig. 5. The relationship between CALIPSO AOD 532 and AMSR-E wind speed for 15 selected regions over the time period of June 2006 to April 2011. The analysis is based on a total 539, 549 collocated data points of AOD and wind speed. The number of available data points for each wind speed bin is plotted at the background in grey color. Dotted line indicates that the AOD - wind speed relationship for $U_{10}>24 \mathrm{~m} \mathrm{~s}^{-1}$ is based on limited number of data points. Circles and error bars show mean values and standard deviation of AOD for each $1 \mathrm{~m} \mathrm{~s}^{-1}$ wind speed bin, respectively. Logistic regression relationship between $\mathrm{AOD}_{532}$ and wind speed is shown with the solid black line.

to $25^{\circ} \mathrm{C}$ (Mårtensson et al., 2003; Sellegri et al., 2006). Further research should be conducted to better quantify the AOD-wind speed relationships over low and high SST regions.

On Fig. 6 the logistic relationship for CALIPSO-AOD 532 and AMSR-E wind speed is compared to linear, exponential and power-law relationships derived in previous studies. Despite some similarities, Fig. 6 shows considerable differences that will be discussed below. Parameters for the current and other regression statistics are summarized in Table 1.

For $U_{10} \leq 4 \mathrm{~m} \mathrm{~s}^{-1}$, the mean CALIPSO derived AOD $_{532}$ of marine aerosols is found to be roughly $0.02 \pm 0.003$. Figure 6 shows that at low wind speed values CALIPSOderived AOD is comparable to $\mathrm{AOD}_{550, \mathrm{~cm}}$ the coarse mode aerosol component of the wind induced marine aerosol optical depth derived by Lehahn et al. (2010). However, Fig. 6 also shows that CALIPSO-AOD 532 is roughly a factor of 3 lower than $\mathrm{AOD}_{550, \mathrm{~m}}$, the total (sum of coarse and fine mode) marine aerosol optical depth calculated using Lehahn et al. (2010) relationship. Our estimated $\mathrm{AOD}_{532}$ is also considerably lower than one calculated using the linear relationship of Smirnov et al. (2003a) $\left(\right.$ AOD $\left._{500, S M}\right)$ and AOD derived by Huang et al. (2010) $\left(\mathrm{AOD}_{550, \mathrm{H}}\right)$, but comparable to values derived from Glantz et al. (2009) regression relationship $\left(\mathrm{AOD}_{555, \mathrm{GL}}\right)$. It is interesting to note that the physical mechanism for the weak dependence of marine aerosol optical depth on surface wind speed at low wind values was suggested to be associated with a threshold wind speed of $\sim 4 \mathrm{~m} \mathrm{~s}^{-1}$, above which ocean surface 


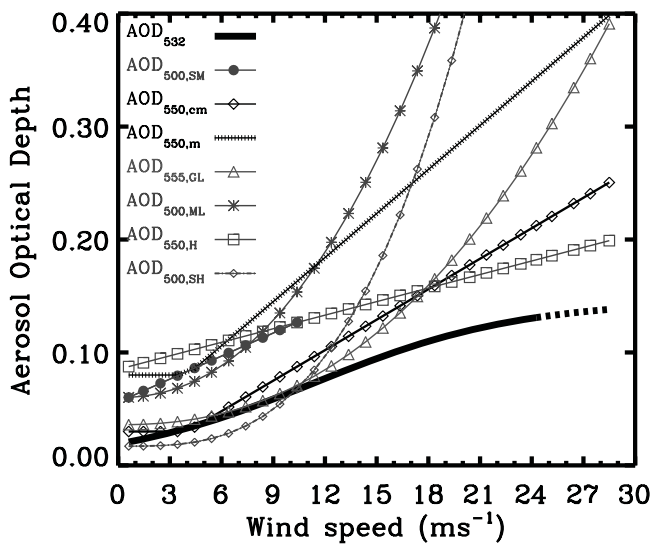

Fig. 6. Marine aerosol optical depth as a function of wind speed. The regression statistics and the acronyms are summarized in Table 1 . See text for more details.

waves start breaking, initiating the white cap formation and bursting of the entrained bubbles (Lehahn et al., 2010). At such low wind-low AOD conditions increasingly larger fraction of marine aerosol volume size distribution can be contributed by sub-micron sized aerosols, with size distribution and chemical composition different from sea salt (de Leeuw et al., 2011). When biogenic particles of marine origin (from marine organics and DMS-oxidized sulfate) comprise significant fraction of optically important aerosols over the ocean the lidar ratio for clean marine aerosol used in CALIPSO retrievals could lead to significant underestimation of $\mathrm{AOD}_{532}$ (see discussion in Sect. 4). However, potential contributions from terrestrial fine mode aerosols (e.g. pollution, smoke and dust) to elevated optical depth values of marine aerosol reported by previous investigators also cannot be ruled out.

For an intermediate wind speed values $4<U_{10} \leq 12 \mathrm{~m} \mathrm{~s}^{-1}$ the dominant production mechanism for sea salt aerosols is the bursting of rising air bubbles. Figure 6 shows that there is a similar linear dependence of AOD on surface wind speed in most of the parameterizations. In this intermediate region, the regression slope derived in this study $\left(0.006 \mathrm{~s} \mathrm{~m}^{-1}\right)$ is consistent with $0.0068 \mathrm{~s} \mathrm{~m}^{-1}$ reported by Smirnov et al. (2003a).

Figure 6 also shows that above a wind speed of $\sim 12 \mathrm{~m} \mathrm{~s}^{-1}$ the current CALIPSO-derived $\mathrm{AOD}_{532}$ values are lower compared to other regressions. Figure 6 shows the discrepancies are particularly pronounced between the AOD values derived in this study and the power law relations of Mulcahy et al. (2008) and Glantz et al. (2009). At high wind speeds, the power law relations show AOD values well above 0.3. It was shown that for the wind speed values below $15 \mathrm{~m} \mathrm{~s}^{-1}$, the relationship of Mulcahy et al. (2008) compares well to open-ocean MODIS-derived AODs, while at wind speeds above $15 \mathrm{~m} \mathrm{~s}^{-1}$, Mulcahy et al. (2008) parameterization predicts higher values compared to satellite retrievals (O'Dowd et al., 2010). Overall, it is difficult to compare AOD val- ues predicted by our logistic relationship with previously published regression statistics at very high wind speed values, as the past data analyses are typically limited to surface wind speed values well below $20 \mathrm{~m} \mathrm{~s}^{-1}$. Nevertheless, according to Fig. 6 CALIPSO-derived AOD $_{532}$ tends to level off at very high wind speeds, asymptotically approaching $\mathrm{AOD}_{532}=0.15$. Although data sets for aerosol loadings under very high wind speed values obtained in different studies often show conflicting results (e.g. Pant et al., 2008), a number of investigators have reported a decrease in sea salt aerosol concentration with an increase in surface wind speed. Exton et al. (1985) reported that above $13 \mathrm{~m} \mathrm{~s}^{-1}$, the measured amount of airborne material in marine air masses remained constant or decreased slightly with increasing wind speed. Barteneva et al. (1991) also noticed no increase in the particle concentrations with wind speeds over $15 \mathrm{~m} \mathrm{~s}^{-1}$. During a severe cyclonic storm over south Indian Ocean Pant et al. (2008) also reported a reduction in total aerosol number concentration with an increase in the wind speed from 16 to $22 \mathrm{~m} \mathrm{~s}^{-1}$ after which the aerosol number remained at a nearly constant value up to the maximum wind speed of $33 \mathrm{~m} \mathrm{~s}^{-1}$. The reason for such reduction in volumetric loading of aerosols with increasing wind speed was explained by the presence of very large sea salt particles. At wind speeds in excess of $\sim 12 \mathrm{~m} \mathrm{~s}^{-1}$, sea spray generation via mechanical disruption of wave crests becomes important (Exton et al., 1985; Wang and Street, 1978; Monahan, 1986; Lewis and Schwartz, 2004). The spume drops torn from the wave crests have relatively large sizes starting from $20 \mu \mathrm{m}$ and reaching more than $500 \mu \mathrm{m}$ (Andreas, 2002). Such large spume drops disperse and deposit more efficiently on the sea surface and may lead to collection of small aerosols during their descent (Exton et al., 1985; Pant et al., 2008). As discussed in Sect. 4 below, it is also possible that leveling off CALIPSO-AOD 532 seen at very high wind speed values is a retrieval artifact.

\section{Caveats and uncertainties}

One of the main caveats in our study arises from the lidar ratio of $20 \pm 6 \mathrm{sr}$ (at $532 \mathrm{~nm}$ ) used for CALIPSO clean marine aerosol retrievals. Such lidar ratio may not be characteristic for all types of natural marine aerosols under variable conditions. The calculated values of $S_{\mathrm{a}}$ for sea spray vary widely, with pronounced differences between super-micron $\left(10 \leq S_{\mathrm{a}} \leq 20\right.$ at $\left.532 \mathrm{~nm}\right)$ and sub-micron $\left(20 \leq S_{\mathrm{a}} \leq 90\right.$ at $532 \mathrm{~nm}$ ) mode particles (Masonis et al., 2003). Therefore, the constant lidar ratio of 20 used by CALIPSO for high confidence clean marine aerosol is largely characteristic of super-micron sea salt particles and could lead to a potential underestimation of sub-micron sea salt or the biogenic fraction of ocean derived aerosols that become increasingly important with decreasing particle size. For example, a lidar ratio as high as $33 \pm 6 \mathrm{sr}$ (at $523 \mathrm{~nm}$ ) has been reported in the absence of any continental influence (Welton et al., 
2002). AERONET database analysis (Smirnov et al., 2003a) also shows $532 \mathrm{~nm}$ lidar ratios of 34.6 (for Lanai) and 33.1 (for Midway Island). When a lidar ratio of 34 is considered, the CALIPSO-derived AOD (at $532 \mathrm{~nm}$ ) increases by a factor of approximately 1.6 (Sayer and Smirnov, personal communications), yielding marine aerosol optical depth values closer to the values suggested by Smirnov et al. (2003a) (see Fig. S2 in Supplement). Overall, this calculation shows that increasing $S_{\mathrm{a}}$ value for clean marine aerosol moves AOD values predicted by current parameterization closer to those previously reported. However, there is no clear consensus that a lidar ratio of 34 may be applicable to the global retrieval of all marine aerosols of different size distributions and chemical compositions. As large uncertainties remain in the source function and chemical properties of sub-micron sea spray aerosol, simultaneous optical and chemical measurements of ambient and laboratory-generated particles at multiple sites and over different seasons are needed to provide better estimates of clean marine aerosol lidar ratio(s).

Uncertainties in remotely sensed wind speed can also influence regression statistics derived in this study. For example, satellites measure instantaneous area-averaged winds that may not be a good indicator for columnar aerosol volume concentration (Bates, 1998; Smirnov et al., 2003a). This may be especially true in regions of rapidly varying wind speeds, and under very low and very high wind conditions. Under very low wind conditions when there is no active production of marine aerosol by bubble bursting, the aerosol size distribution is likely to be dominated by the aerosols resulting from transport and/or produced by gas to particle conversion with the concentration footprint of tens of km upwind the measurement location (Ceburnis et al., 2008). At stronger wind speeds there is an increased probability that the CALIPSO lidar signal can be contaminated with multiple scattering effects from whitecaps, the correction for which is not included in current CALIPSO aerosol algorithm. Hu et al. (2008) noticed significant improvements in relationship between AMSR-E wind speed and CALIPSO lidar backscatter when they applied whitecaps correction in their analysis for higher wind speeds. Further evaluation of CALIPSOderived marine aerosol AOD behavior is required under very low and very high wind conditions.

\section{Summary and conclusion}

Analysis of remotely sensed data for marine aerosol optical depth and surface wind speed values has been conducted over the global ocean covering wide range of wind speed and AOD conditions. In order to exclude the contribution from non-marine aerosol such as urban/industrial pollution, desert dust and biomass burning, the marine aerosol $\mathrm{AOD}_{532}$ was calculated using CALIPSO derived "clean marine" aerosol subtype. Daily surface wind speed data were obtained from the AMSR-E. Detailed data analyses were carried out over 15 regions selected to be representative of different areas of the global oceans for the time period from June 2006 to April 2011. A logistic relationship between CALIPSO-retrieved AOD $_{532}$ and AMSR-E wind speed was derived using over half a million collocated data points. The global mean single-layer $\mathrm{AOD}_{532}$ was found to be $0.052 \pm 0.038$, consistent with the previous estimates of baseline aerosol optical depth over the Pacific and Atlantic Oceans. The mean layer integrated particulate depolarization ratio of marine aerosols was found to be $0.02 \pm 0.016$. Integrated attenuated backscatter and the color ratio of the marine aerosols at $532 \mathrm{~nm}$ were found to be $0.003 \pm 0.002 \mathrm{sr}^{-1}$ and $0.530 \pm 0.149$, respectively.

Derived logistic regression between CALIPSO-retrieved $\mathrm{AOD}_{532}$ and AMSR-E wind speed indicates a weak relationship at low wind speed values $\left(U_{10} \leq 4 \mathrm{~m} \mathrm{~s}^{-1}\right)$. This result is consistent with previous studies, suggesting that $\mathrm{AOD}_{532}$ at surface wind speed $\leq 4 \mathrm{~m} \mathrm{~s}^{-1}$ can be viewed to be representative of background marine aerosol with little dependence on surface wind speed. Our data analysis shows that under such low wind conditions CALIPSO-derived $\mathrm{AOD}_{532}$ is roughly a factor of 2 lower compared to previously reported values of total marine aerosol AOD, but consistent with its wind induced component (Lehahn et al., 2010). We proposed that such an inconsistency is likely to be caused by the potential underestimation of sub-micron aerosol by CALIPSO and/or contribution from terrestrial fine mode aerosols (e.g. pollution, smoke and dust) in previous works. Studies show that ocean derived sulfate and organics can contribute considerably to total aerosol budget, particularly under low wind conditions when bursting of the entrained air bubbles is rather ineffective mechanism for the production of sea salt.

At intermediate wind speed values $\left(4<U_{10} \leq 12 \mathrm{~m} \mathrm{~s}^{-1}\right)$, the logistic regression relationship derived in this study between clean marine aerosol and surface wind speed has a constant slope of $0.006 \mathrm{~s} \mathrm{~m}^{-1}$. Our calculations suggest that in this intermediate range, which represents the dominant fraction of all available data, CALIPSO-derived $\mathrm{AOD}_{532}$ dependence on $U_{10}$ is consistent with previously reported regression relationships.

At high wind speed values $\left(U_{10}>12 \mathrm{~m} \mathrm{~s}^{-1}\right)$ our logistic regression predicts $\mathrm{AOD}_{532}$ values lower than ones derived using linear, exponential, and power-law relationships. Analysis of CALIPSO-retrieved AOD 532 and AMSR-E wind speed suggests that at very high wind speed values aerosol effects on optical turbidity of atmosphere appear to level off, asymptotically approaching value of 0.15 . However, such conclusions may also have been influenced by potential contamination of CALIPSO lidar signal by whitecaps. Further studies with simultaneous optical and chemical measurements of ambient and laboratory-generated particles are required to better evaluate the marine aerosol AOD behavior under low and high wind conditions and elucidate the potential inaccuracies in aerosol extinction profiles caused by the constant lidar ratio assumption. 


\section{Supplementary material related to this article is available online at: http://www.atmos-chem-phys.net/11/11401/2011/ acp-11-11401-2011-supplement.pdf.}

Acknowledgements. This research was supported by the Office of Science (BER), US Department of Energy, grant No. DEFG02-08ER64508 and by the National Aeronautics \& Space Administration (NASA) through grant no NNX11AG72G. We thank Yongxiang $\mathrm{Hu}$, Alexander Smirnov, Andrew Sayer and Santiago Gassó for fruitful discussions. We also would like to thank four anonymous reviewers for their helpful suggestions. The authors gratefully acknowledge the CALIPSO and AMSR-E Teams for their effort in making the data available. CALIPSO data were obtained from the NASA Langley Research Center Atmospheric Science Data Center. AMSR-E data are produced by Remote Sensing Systems and sponsored by the NASA Earth Science MEaSUREs DISCOVER Project and the AMSR-E Science Team. Data are available at www.remss.com.

Edited by: R. Volkamer

\section{References}

Andreae, M. O.: Aerosols before pollution, Science, 315, 5808, 5051, doi:10.1126/science.1136529, 2007.

Andreas, E. L.: A review of the sea spray generation function for the open ocean,Atmosphere-Ocean Interactions,edited by: Perrie, W. A., WIT Press, Southampton, UK, 1, 1-46, 2002.

Barteneva, O. D., Nikitinskaya, N. I., Sakunov, G. G., and Veselova, L. K.: Atmospheric transmittance in the visible and near IR spectral range, 224 pp., Gidrometeoizdat, Leningrad, 1991 (in Russian).

Bates, T. S., Kapustin, V. N., Quinn, P. K., Covert, D. S., Coffman, D. J., Mari, C., Durkee, P. A., Bruyn, W. J. D., and Saltzman, E. S.: Processes controlling the distribution of aerosol particles in the lower marine boundary layer during the First Aerosol Characterization Experiment (ACE 1), J. Geophys. Res., 103, 1636916383, 1998.

Blanchard, D. C. and Woodcock, A. H.: Bubble formation and modification in the sea and its meteorological significance, Tellus, 9, 145-158, 1957.

Bourassa, M., Stoffelen, A., Bonekamp, H., Chang, P., Chelton, D. B., Courtney, J., Edson, R., Figa, J., He, Y., Hersbach, H., Hilburn, K., Jelenak, Z., Kelly, K. A., Knabb, R., Lee, T., Lindstrom, E. J., Liu, W. T., Long, D. G., Perrie, W., Portabella, M., Powell, M., Rodriguez, E., Smith, D. K., Swail, V., and Wentz, F. J.: Remotely Sensed Winds and Wind Stresses for Marine Forecasting and Ocean Modeling in Proceedings of OceanObs'09: Sustained Ocean Observations and Information for Society (Vol. 2), Venice, Italy, 21-25 September 2009, edited by: Hall, J., Harrison, D. E., and Stammer, D., ESA Publication WPP-306, doi:10.5270/OceanObs09.cwp.08, 2009.

Cattrall, C., Reagan, J., Thome, K., and Dubovik, O.: Variability of aerosol and spectral lidar and backscatter and extinction ratios of key aerosol types derived from selected Aerosol Robotic Network locations, J. Geophys. Res., 110, D10S11, doi:10.1029/2004JD005124, 2005.
Ceburnis, D., O’Dowd, C. D., Jennings, G. S., Facchini, M. C., Emblico, L., Decesari, S., Fuzzi, S., and Sakalys, J.: Marine aerosol chemistry gradients: Elucidating primary and secondary processes and fluxes, Geophys. Res. Lett., 35, L07804, doi:10.1029/2008GL033462, 2008.

Charlson, R. J., Lovelock, J. E., Andreae, M. O., and Warren, S. G.: Oceanic phytoplankton, atmospheric sulphur, cloud albedo and climate, Nature, 326, 655-661, doi:10.1038/326655a0, 1987.

Clarke, A. D. and Kapustin, V. N.: The Shoreline Environment Aerosol Study (SEAS): A context for marine aerosol measurements influenced by a coastal environment and long-range transport, J. Atmos. Ocean. Tech., 20, 1351-1361, 2003.

de Leeuw, G., Andreas, E. L., Anguelova, M. D., Fairall, C. W., Lewis, E. R., O’Dowd, C., Schulz, M., and Schwartz, S. E.: Production flux of sea spray aerosol, Rev. Geophys., 49, RG2001, doi:10.1029/2010RG000349, 2011.

Exton, H. J., Latham, J., Park, P. M., Perry, S. J., Smith, M. H., and Allan R. R.: The production and dispersal of marine aerosol, Q. J. Roy. Meteor. Soc., 111, 817-837, 1985.

Glantz, P., Nilsson, E., and von Hoyningen-Huene, W.: Estimating a relationship between aerosol optical thickness and surface wind speed over the ocean, Atmos. Res., 92, 58-68, doi:10.1016/j.atmosres.2008.08.010, 2009.

Gobbi, G. P., Barnaba, F., Giorgi, R., and Santacasa, A.: Altitude resolved properties of a Saharan dust event over the Mediterranean, Atmos. Environ., 34, 5119-5127, doi:10.1016/S13522310(00)00194-1, 2000.

Grini, A., Myhre, G., Sundet, J. K., and Isaksen, I. S. A.: Modeling the annual cycle of sea salt in the global 3D model Oslo CTM2: Concentrations, fluxes, and radiative impact, J. Climate, 15, 1717-1730, 2002.

Holben, B. N., Eck, T. F., Slutsker, I., Tanre, D., Buis, J. P., Setzer, A., Vermote, E., Reagan, J. A., Kaufman, Y. J., Nakajima, T., Lavenu, F., Jankowiak, I., and Smirnov, A.: AERONET - A federated instrument network and data archive for aerosol characterization, Remote Sens. Environ., 66, 1-16, 1998.

Hunt, W., Winker, D., Vaughan, M., Powell, K., Lucker, P., and Weimer, C.: CALIPSO lidar description and performance assessment, J. Atmos. Ocean. Tech., 26, 1214-1228, 2009.

Hu, Y., Vaughan, M., McClain, C., Behrenfeld, M., Maring, H., Anderson, D., Sun-Mack, S., Flittner, D., Huang, J., Wielicki, B., Minnis, P., Weimer, C., Trepte, C., and Kuehn, R.: Global statistics of liquid water content and effective number concentration of water clouds over ocean derived from combined CALIPSO and MODIS measurements, Atmos. Chem. Phys., 7, 3353-3359, doi:10.5194/acp-7-3353-2007, 2007.

Hu, Y., Stamnes, K., Vaughan, M., Pelon, J., Weimer, C., Wu, D., Cisewski, M., Sun, W., Yang, P., Lin, B., Omar, A., Flittner, D., Hostetler, C., Trepte, C., Winker, D., Gibson, G., and Santa-Maria, M.: Sea surface wind speed estimation from spacebased lidar measurements, Atmos. Chem. Phys., 8, 3593-3601, doi:10.5194/acp-8-3593-2008, 2008.

Huang, H., Thomas, G. E., and Grainger, R. G.: Relationship between wind speed and aerosol optical depth over remote ocean, Atmos. Chem. Phys., 10, 5943-5950, doi:10.5194/acp-10-59432010, 2010.

Jaeglé, L., Quinn, P. K., Bates, T. S., Alexander, B., and Lin, J.-T.: Global distribution of sea salt aerosols: new constraints from in situ and remote sensing observations, Atmos. Chem. Phys., 11, 
3137-3157, doi:10.5194/acp-11-3137-2011, 2011.

Kaufman, Y., Smirnov, A., Holben, B., and Dubovik, O.: Baseline maritime aerosol: methodology to derive the optical thickness and scattering properties, Geophys. Res. Lett., 17, 3251-3254, doi:10.1029/2001GL013312, 2001.

Kaufman, Y. J., Koren, I., Remer, L. A., Tanré, D., Ginoux, P., and Fan, S.: Dust transport and deposition observed from the Terra-Moderate Resolution Imaging Spectroradiometer (MODIS) spacecraft over the Atlantic Ocean, J. Geophys. Res., 110, D10S12, doi:10.1029/2003JD004436, 2005.

Kittaka, C., Winker, D. M., Vaughan, M. A., Omar, A., and Remer, L. A.: Intercomparison of column aerosol optical depths from CALIPSO and MODIS-Aqua, Atmos. Meas. Tech., 4, 131-141, doi:10.5194/amt-4-131-2011, 2011.

Lehahn, Y., Koren, I., Boss, E., Ben-Ami, Y., and Altaratz, O.: Estimating the maritime component of aerosol optical depth and its dependency on surface wind speed using satellite data, Atmos. Chem. Phys., 10, 6711-6720, doi:10.5194/acp-10-67112010, 2010.

L'Ecuyer, T. S. and Jiang, J. H.: Touring the atmosphere aboard the A-Train, Phys. Today, 63, 36-41, doi:10.1063/1.3463626, 2010.

Lewis, R. and Schwartz, S. E.: Sea Salt Aerosol Production: Mechanisms, Methods, Measurements, and Models - A Critical Review, Geophysical monograph 152, American Geophysical Union, Washington, DC, 413 pp., 2004.

Liu, Z., Vaughan, M. A., Winker, D. M., Hostetler, C. A., Poole, L., Hlavka, D., Hart, W., and McGill, M.: Use of probability distribution functions for discriminating between cloud and aerosol in lidar backscatter data, J. Geophys. Res., 109, D15202, doi:10.1029/2004JD004732, 2004.

Liu, Z., Omar, A. H., Hu, Y., Vaughan, M. A., and Winker, D. M.: CALIOP Algorithm Theoretical Basis Document, Part 3: Scene Classification Algorithms, Release 1.0, PC-SCI-202, NASA Langley Research Center, Hampton, VA, 56, available online at: http://www-calipso.larc.nasa.gov/resources/pdfs/ PC-SCI-202_Part3_v1.0.pdf, 2005.

Liu, Z., Vaughan, M. A., Winker, D. M., Kittaka, C., Getzewich, B. J., Kuehn, R. E., Omar, A. H., Powell, K., Trepte, C. R., and Hostetler, C. A.: The CALIPSO Lidar Cloud and Aerosol Discrimination: Version 2 Algorithm and Initial Assessment of Performance, J. Atmos. Ocean. Tech., 26, 1198-1213, doi:10.1175/2009JTECHA1229.1, 2009.

Maring, H., Savioe, D. L., Izaguirre, M. A., Custals, L., and Reid, J. S.: Vertical distributions of dust and sea-salt aerosols over Puerto Rico during PRIDE measured from a light aircraft, J. Geophys. Res., 108, 8587, doi:10.1029/2002JD002544, 2003.

Mårtensson, E. M., Nilsson, E. D., de Leeuw, G., Cohen, L. H., and Hansson, H. C.: Laboratory simulations and parameterization of the primary marine aerosol production, J. Geophys. Res., 108, 4297, doi:10.1029/2002jd002263, 2003.

Masonis, S. J., Anderson, T. L., Covert, D. S., Kapustin, V., Clarke, A. D., Howell, S., and Moore, K.: A study of the extinctionto-backscatter ratio of marine aerosol during the Shoreline Environment Aerosol Study, J. Atmos. Ocean. Tech., 20, 1388-1402, 2003.

Mears, C. A., Smith, D. K., and Wentz, F. J.: Comparison of special sensor microwave imager and buoy-measured wind speeds from 1987-1997, J. Geophys. Res., 106, 11719-11729, 2001.

Meskhidze, N. and Nenes, A.: Phytoplankton and cloudi- ness in the Southern Ocean, Science, 314, 1419, doi:10.1126/science.1131779, 2006.

Mielonen, T., Arola, A., Komppula, M., Kukkonen, J., Koskinen, J., de Leeuw, G., and Lehtinen, K. E. J.: Comparison of CALIOP level 2 aerosol subtypes to aerosol types derived from AERONET inversion data, Geophys. Res. Lett., 36, L18804, doi:10.1029/2009GL039609, 2009.

Monahan, E. C., Spiel, D. E., and Davidson, K. L.: A model of marine aerosol generation via whitecaps and wave disruption, in Oceanic whitecaps and their role in air-sea exchange processes, edited by: Monahan, E., Niocaill, G. M., and Reidel, D., Norwell, Mass, 167-174, 1986.

Moorthy, K. K. and Satheesh, S. K.: Characteristics of aerosols over a remote island, Minicoy in the Arabian Sea: optical properties and retrieved size characteristics, Q. J. Roy. Meteor. Soc., 126, 81-109, doi:10.1002/qj.49712656205, 2000.

Mulcahy, J. P., O’Dowd, C. D., Jennings, S. G., and Ceburnis, D.: Significant enhancement of aerosol optical depth in marine air under high wind conditions, Geophys. Res. Lett., 35, L16810, doi:10.1029/2008GL034303, 2008.

Murayama, T., Sugimoto, N., Uno, I., Kinoshita, K., Aoki, K., Hagiwara, N., Liu, Z., Matsui, I., Sakai, T., Shibata, T., Arao, K., Sohn, B., Won, J., Yoon, S., Li, T., Zhou, J., Hu, H., Abo, M., Iokibe, K., Koga, R., and Iwasaka, Y.: Ground-based network observation of Asian dust events of April 1998 in East Asia, J. Geophys. Res., 106, 18345-18359, doi:10.1029/2000JD900554, 2001.

Murphy, D. M., Anderson, J. R., Quinn, P. K., McInnes, L. M., Brechtel, F. J., Kreidenweis, S. M., Middlebrook, A. M., P'osfai, M., Thomson, D. S., and Buseck, P. R.: Influence of sea-salt on aerosol radiative properties in the Southern Ocean marine boundary layer, Nature, 392, 62-65, doi:10.1038/32138, 1998.

O'Dowd, C. D. and de Leeuw, G.: Marine aerosol production: A review of the current knowledge, Phil. Trans. R. Soc. A: Mathematical, Phys. Eng. Sci., 365, 1753-1774, doi:10.1098/rsta.2007.2043, 2007.

O’Dowd, C. D., Facchini, M. C., Cavalli, F., Ceburnis, D., Mircea, M., Decesari, S., Fuzzi, S., Yoon, Y. J., and Putaud, J.-P.: Biogenically driven organic contribution to marine aerosol, Nature, 431, 7009, 676-680, doi:10.1038/nature02959, 2004.

O’Dowd, C., Scannell, C., Mulcahy, J., and Jennings, S. G.: Wind Speed Influences on Marine Aerosol Optical Depth, Adv. Meteorol., 2010, 830846, doi:10.1155/2010/830846, 2010.

O'Neill, L. W., Chelton, D. B., and Esbensen, S. K.: Observations of SST-induced perturbations of the wind stress field over the Southern Ocean on seasonal timescales. J. Climate, 16, 2340 2354, 2003.

Omar, A. H. and Babakaeva, T.: Aerosol optical properties derived from lidar observations using cluster analysis, Geoscience and Remote Sensing Symposium, 2004, IGARSS '04, Proceedings, 2004 IEEE International, 3, 2212-2215, doi:10.1109/IGARSS.2004.1370800, 2004.

Omar, A., Won, J., Winker, D., Yoon, S., Dubovik, O., and McCormick, M.: Development of global aerosol models using cluster analysis of Aerosol Robotic Network (AERONET) measurements, J. Geophys. Res., 110, D10S14, doi:10.1029/2004JD004874, 2005.

Omar, A., Winker, D., Vaughan, M., Hu, Y., Trepte, C., Ferrare, R., Lee, K., Hostetler, C., Kittaka, C., Rogers, R., Kuehn, R., 
and Liu, Z.: The CALIPSO Automated Aerosol Classification and Lidar Ratio Selection Algorithm, J. Atmos. Ocean. Tech., 26, 1994-2014, doi:10.1175/2009JTECHA1231.1, 2009.

Pant, V., Deshpande, C. G., and Kamra, A. K.: On the aerosol number concentration-wind speed relationship during a severe cyclonic storm over south Indian Ocean, J. Geophys. Res., 113, D02206, doi:10.1029/2006JD008035, 2008.

Penner, J. E., Charlson, R. J., Hales, J. M., Laulainen, N. S., Leifer, R., Novakov, T., Ogren, J., Radke, L. F., Schwartz, S. E., and Travis, L.: Quantifying and minimizing uncertainty of climate forcing by anthropogenic aerosols, B. Am. Meteorol. Soc., 75, 375-400, 1994.

Pierce, J. R. and Adams, P. J.: Global evaluation of CCN formation by direct emission of sea salt and growth of ultrafine sea salt, J. Geophys. Res., 111, D06203, doi:10.1029/2005JD006186, 2006.

Platnick, S. and Twomey, S.: Determining the susceptibility of cloud albedo to changes in droplet concentration with the advanced very high resolution radiometer, J. Appl. Meteorol., 33, 334-347, 1994.

Prospero, J. M.: The chemical and physical properties of marine aerosols: An introduction, in Chemistry of Marine Water and Sediments, edited by: Gianguzza, A., Pelizzetti, E., and Sammartano, S., Springer-Verlag, 35-82, 2002.

Rind, D., Chin, M., Feingold, G., Streets, D., Kahn, R. A., Schwartz, S. E., and Yu, H.: Modeling the Effects of Aerosols on Climate, in Atmospheric Aerosol Properties and Climate Impacts, A Report by the U.S. Climate Change Science Program and the Subcommittee on Global Change Research, edited by: Chin, M., Kahn, R. A., and Schwartz, S. E., National Aeronautics and Space Administration, Washington, DC, USA, 2009.

Rogers, R. R., Hair, J. W., Hostetler, C. A., Ferrare, R. A., Obland, M. D., Cook, A. L., Harper, D. B., Burton, S. P., Shinozuka, Y., McNaughton, C. S., Clarke, A. D., Redemann, J., Russell, P. B., Livingston, J. M., and Kleinman, L. I.: NASA LaRC airborne high spectral resolution lidar aerosol measurements during MILAGRO: observations and validation, Atmos. Chem. Phys., 9, 4811-4826, doi:10.5194/acp-9-4811-2009, 2009.

Sakai, T., Nagai, T., Zaizen, Y., and Mano, Y.: Backscattering linear depolarization ratio measurements of mineral, sea-salt, and ammonium sulfate particles simulated in a laboratory chamber, Appl. Optics, 49, 4441-4449, 2010.

Sellegri, K., O’Dowd, C. D., Yoon, Y. J., Jennings, S. G., and de Leeuw, G.: Surfactants and submicron sea spray generation, J. Geophys. Res., 111, D22215, doi:10.1029/2005JD006658, 2006.

Shaw, G. E.: Bio-controlled thermostasis involving the sulfur cycle, Climatic Change, 5, 297-303, doi:10.1007/BF02423524, 1983.

Shinozuka, Y., Clarke, A. D., Howell, S. G., Kapustin, V. N., and Huebert, B. J.: Sea-salt vertical profiles over the Southern and tropical Pacific oceans: Microphysics, optical properties, spatial variability, and variations with wind speed, J. Geophys. Res., 109, D24201, doi:10.1029/2004JD004975, 2004.

Smirnov, A., Holben, B., Eck, T., Dubovik, O., and Slutsker, I.: Effect of wind speed on columnar aerosol optical properties at Midway Island, J. Geophys. Res., 108, 4802, doi:10.1029/2003JD003879, 2003a.
Smirnov, A., Holben, B., Dubovik, O., Frouin, R., Eck, T., and Slutsker, I.: Maritime component in aerosol optical models derived from Aerosol Robotic Network data, J. Geophys. Res., 108, 4033, doi:10.1029/2002JD002701, 2003b.

Vaughan, M. A., Young, S. A., Winker, D. M., Powell, K. A., Omar, A. H., Liu, Z., Hu, Y., and Hostetler, C. A.: Fully automated analysis of space-based lidar data: an overview of the CALIPSO retrieval algorithms and data products, Proc. SPIE, 5575, 16-30, 2004.

Vaughan, M. A., Winker, D. M., and Powell, K. A.: CALIOP Algorithm Theoretical Basis Document, Part 2: Feature Detection and Layer Properties Algorithms, PC-SCI-202, Release 1.01, 87 pp., NASA Langley Research Center, Hampton, VA, 56 , available at: http://www-calipso.larc.nasa.gov/resources/pdfs/ PC-SCI-202_Part2_rev1x01.pdf, 2005.

Vaughan, M. A., Powell, K. A., Winker, D. M., Hostetler, C. A., Kuehn, R. E., Hunt, W. H., Getzewich, B. J., Young, S. A., Liu, Z., and McGill, M. J.: Fully automated detection of cloud and aerosol layers in the CALIPSO lidar measurements, J. Atmos. Oceanic Technol., 26, 2034-2050, 2009.

Wang, C. S. and Street, R. L.: Transfers Across an Air-Water Interface at High Wind Speeds: The Effect of Spray, J. Geophys Res., 83, 2959-2969, doi:10.1029/JC083iC06p02959, 1978.

Weitkamp, C.: Lidar: range-resolved optical remote sensing of the atmosphere, Springer Science, 455 pp., 2005.

Welton, E. J., Voss, K. J., Quinn, P. K., Flatau, P. J., Markowicz, K., Campbell, J. R., Spinhirne, J. D., Gordon, H. R., and Johnson, J. E.: Measurements of aerosol vertical profiles and optical properties during INDOEX 1999 using micropulse lidars, J. Geophys. Res., 107, 8019, doi:10.1029/2000JD000038, 2002.

Wentz, F. J. and Meissner, T.: AMSR Ocean Algorithm Theoretical Basis Document, Version 2, report number 121599A-1, Remote Sensing Systems, Santa Rosa, CA, 2000.

Wentz, F. J. and Meissner, T.: AMSR-E Ocean Algorithms, report number 051707, Remote Sensing Systems, Santa Rosa, CA, 6 pp., 2007.

Wentz, F. J., Gentemann, C., and Ashcroft, P.: On-orbit calibration of AMSR-E and the retrieval of ocean products, 83rd AMS Annual Meeting, American Meteorological Society, Long Beach, CA, 2003.

Winker, D. M. and Pelon, J.: The CALIPSO mission, Geoscience and Remote Sensing Symposium, IGARSS '03, Proceedings, IEEE International, 2, 1329-1331, 2003.

Winker, D. M., Vaughan, M. A., Omar, A. H., Hu, Y., Powell, K. A., Liu, Z., Hunt, W. H., and Young, S. A.: Overview of the CALIPSO Mission and CALIOP Data Processing Algorithms, J. Atmos. Ocean. Tech., 26, 2310-2323, 2009.

Xie, S.-P.: Satellite observations of cool ocean-atmosphere interaction, BAMS, 85, 195-208, 2004.

Young, S. A. and Vaughan, M. A.: The retrieval of profiles of particulate extinction from Cloud Aerosol Lidar Infrared Pathfinder Satellite Observation (CALIPSO) data: Algorithm description, J. Atmos. Ocean. Tech., 26, 1105-1119, 2009. 